\title{
Paleo-Historical Fluctuations in Paleogeography, Depositional Environment, and Chemistry of Eocene Fossil LaKe
}

\author{
H. PAUl BuchHEIM \\ DEPARTMENT OF NATURAL SCIENCES ^ LOMA LiNDA UNIVERSITY \\ LOMA LiNDA, CALIFORNIA
}

\begin{abstract}
Fossil Butte National Monument contains within its boundaries, a significant portion the world's best preserved and most complete ancient lake deposit, known as the Fossil Butte and Angelo Members of the Green River Formation (Oriel and Tracy 1970). Fossil Lake, the Eocene depository of these members of the Green River Formation, occupied a north-south trending structural basin within the Wyoming Thrust Belt known as Fossil Basin. Within Fossil Basin one can follow individual time horizons or rock units from lake center to margin with relative ease and great accuracy. Those rock units have faithfully recorded lake center to lake margin differences in lake depth, turbidity, salinity, alkalinity, temperature, and faunal elements. Areal changes in thickness and lithology (rock type) can be measured and mapped revealing details of lake shape, geography, and regional differences in lake depth and chemistry. Details concerning location and size of fluvial inlets and deltas, variations in lake bottom gradient and sediment type, and how these relate to flora and fauna can be discerned. An understanding of these aspects of the ancient lake system are essential if paleontologists are to put together a complete picture of the lake's fish fauna, which is the focal point of the monument. A variety of basin analysis maps derived from data collected in the field and laboratory will be used to make paleoenvironmental and paleogeographical interpretations of Fossil Lake through time.
\end{abstract}

\section{$\downarrow$ OвJectives}

The primary objective of this research is to determine the paleogeograpy, depositional environment, and chemistry of Eocene Fossil Lake and to document how these aspects fluctuated through time. The result will be a series of "time slice" maps portraying the widely differing characters of Fossil Lake throughout it's history. The aerial maps will show (when and where possible) lake margin boundaries, location of major inflow rivers, deltas, lake bottom gradient, variations in lake chemistry (salinity and alkalinity), variations of lake depth, location of subaqueous turbidity flow channels, sediment or facies distributions, Eh or oxygen conditions of the bottom sediment and water column, proximity and probable location of volcanic vents near the lake, and distribution of bottom dwelling bioturbators. These maps will be interpretive maps based on numerous data maps (isolith and isogrid, facies, mineral distribution, isotope variation, etc.) produced by plotting of sedimentary structure, facies, petrograph i.e., mineralogic, unit thickness, total organic carbon, isotopic (oxygen), and other related data. Paleontologic data will be included where available, or easily observed in hand samples (primarily ostracods, gastropods, trace fossils and plant remains). 


\section{$\downarrow$ METHODS}

During the 1990 field season spent sampling 13 sedimentary beds were sampled at 26 different locations throughout Fossil Basin and within Fossil Butte National Monument. These locations were located at about one kilometer intervals along outcrops of the Fossil Butte Member within Fossil Basin. Outcrops, exposing the 13 sedimentary units described above, occur along canyons and buttes within the mapped area. At most locations, the units were well exposed. Samples consisted of hand size rock samples that were labeled and vertical orientation indicatived with an arrow. Sample locations were plotted on topographic maps and air photos. Thickness of section was also measure between sample intervals.

Rock samples, 260 collected in the field have been slabbed, polished, acid etched and stained so as to allow detailed sedimentological analysis. X-ray diffraction, thin-sectioning, and isotope analysis will be conducted before the beginning of the 1991 field season. Data obtained will be entered into a Geographic Information Systems program and plotted out as a series of paleogeographic maps showing unit thickness variations, mineralogic variations, laminae frequency variations, etc.

\section{$\downarrow \quad$ Preliminary Results}

When the sample preparation and analysis is completed, the resultant data entered into a Geographic Information System program, maps will be plotted and results and conclusions will be made. Lithologic and thickness variations from location to location appear important and should reveal some important variations when plotted as paleo-geographic maps.

\section{$\downarrow \quad$ Literature Cited}

Oriel, S.S., and J.I. Tracy, Jr. 1970, Uppermost Cretaceous and Tertiary stratigraphy of Fossil Basin, southwestern Wyoming: USGS Professional Paper 635, 53 p. 